\title{
Diatremes cut through the Triassic carbonate platforms in the Dolomites? Evidences from and around the Latemar, northern Italy
}

1 Institute of Natural Resources, Volcanic Risk Solutions, Massey University, Palmerston North, New Zealand. Email: k.nemeth@massey.ac.nz 2 Department of Geological Research, Geological Institute of Hungary, Stefánia út 14, Budapest, H-1143, Hungary. Email: budai@mafi.hu

Widespread volcanism associated with Middle Triassic carbonate platforms is well known, and in many cases referred as a partial cause of the disruption of platform development due to burial by volcanic material. It is no doubt that silicic explosive volcanism produced large volume of volcanic material accumulated in basins surrounding the carbonate platforms (Buchenstein basins) alternating with pelagic carbonates of basin facies. There are large numbers of mafic eruptive products associated with individual carbonate platforms such as the Latemar in the Dolomites in northern Italy. These eruptive products are dominated by mafic dyke swarms which due to their more erodable nature provide a characteristic castle-like architecture of the present day edifice, having altered mafic dyke material eroded away between more resistant limestone and dolomite pillars. Here we present field evidences to demonstrate that there are characteristic zones of volcaniclastic vertical breccia horizons more consistent with diatreme origin. In many occasions, such volcanic breccia pipes and associated tilted blocks were used for demonstrating the casual relationship between tectonic event-generated collapsed carbonate platform units and accumulation of volcanic material in the resulting basins. Here we concur with this idea, and provide field evidences that such volcanic breccia pipes are rather exposed volcanic conduits, resulted from magma and water interaction driven diatreme formation. This finding from the Latemar in northern Italy highlights the need of revision of the cause and consequences of different types of volcanism in the final episodes of the carbonate platform evolution in the Triassic of the Tethys.

\section{Introduction}

Carbonate platform development in active tectonic settings is commonly influenced by synsedimentary movements caused by tectonic processes forming the basins where the platform grows. Such processes have been studied in great detail from many well-known carbonate platforms including the Albian of Larranto, Spain (Fernández-Mendiola and García-Mondéjar, 2003), in the Middle Triassic of the Bakony Mts, western Hungary (Budai and Vörös, 1993, 2006) and many places from the Triassic carbonate platforms in northern Italy (Bosellini 1984; Bosellini et al. 1996, 2003; De Zanche et al. 1993; Gianolla et al. 1998), etc. Perhaps not only the tectonic processes may form characteristic features across evolving carbonate platform, but they can be associated with various volcanic event generated features, especially with widespread dyke swarm development. Mafic dyke intrusions are well-documented in many carbonate platforms and studied in regard to draw a basin evolution model, and the potential influence of these magmatic processes on evolution of carbonate platforms. Volcanism through carbonate platforms have been studied in many ways in the past, however, the potential implication on the style of resulting volcanism has recently been rediscovered (e.g. Martin et al. 2004; Basile and Chauvet, 2009). Volcanic eruption triggered by small-volume mafic magmas in shallow subaqueous environment produces hydromagmatic explosive eruptions commonly form subaqueous pyroclastic mounds that can grow over the water surface building up tuff cones (e.g. Sohn, 1996; Németh et al. 2006). Half sections of eroded tuff cones reveal complex shifting and lithofacies changes through the early to late stage eruptive products of the growing tuff cone (e.g. White, 1996; Brand and Clarke, 2009). In subaerial conditions the rising mafic magma can encounter ground and surface water forming tuff rings and maars (e.g. White 1991a; Manville et al. 2009). The style of magma and water interaction causing explosive eruptions is controlled by the hydrogeological characteristics of the sediments and rocks the magma encountered. In pure subaerial conditions the water saturation of loose sediment (commonly referred as "soft rocks" environment), the water content, permeability and hydraulic conductivity of rocks (commonly referred as "hard rock" environment) are key parameters to control the style of magma and water interaction. As a result in eroded and exposed pyroclastic debris filled volcanic conduits a great variety of rock textures can be identified from intrusive processes associated with melt invading the vent zone (e.g. Martin and Németh, 2007; Németh and Martin, 2007) to fragmentation and early dispersal of volcanic debris from the fragmentation site (e.g. Ross and White, 2006; Lorenz, 1974; Ross et al. 2008a, b). Eruption through a carbonate platform is expected to be special due to its high water storage capacity in deep zones in fractures and pores, its topmost unconsolidated and water-saturated zone as well as the shallow (few metres) water table above the platform. 
Due to the abundance of water in various types of water sources as well as the shallow water cover over the platform suggestive for a special environment, phreatomagmatic eruptions are likely and diatremes are prone to form. In this paper we present some field evidences from the Latemar Triassic carbonate platform to demonstrate that diatremes formed and are well-preserved today in this area.

\section{Geological Setting}

During the Middle Triassic the Dolomites (Fig. 1A, B) belonged to the wide continental shelf of the westernmost part of the Tethys ocean bay. Due to intensive tectonic activity in the latest Anisian and in the Ladinian isolated carbonate platforms developed, separated by tectonically controlled deep interplatform basins (Bosellini, 1984; De Zanche et al. 1993; Bosellini et al. 1996; Gianolla et al. 1998). Synsedimentary tectonic movements were accompanied and followed by strong volcanic activity, characterized by rhyolitic explosions during the late Anisian and by andesitic to basaltic lava flows in the Ladinian (Pisa et al. 1980; Bosellini et al. 1996).

The relatively small isolated Middle Triassic carbonate platform of the Latemar (Figs. 1B, C, D) is one of the most famous Triassic platforms of the western Dolomites (Gaetani et al. 1981; Egenhoff et al. 1999; Bechstädt et al. 2003). The main part of the platform is built up by cyclic peritidal to subtidal lagoon facies of the Sciliar (Schlern) Formation. The platform is surrounded by pelagic sediments of the coeval basins (Buchenstein Formation).

The spectacular exposure of the Dolomites gives the possibility to investigate almost the original paleogeography of the platform edifices and the adjacent basins; however, the relationship of the different sedimentary environments with the surrounding intrusions and subvolcanic bodies (Predazzo, Monzoni) is much less evident.

Carbonate platform evolution is commonly separated into two distinct phases in the Dolomite region; (1) pre-volcanic (late Anisian - middle Ladinian) and (2) post-volcanic platform development (late Ladinian - Carnian) (Bosellini et al. 2003). These two generations of platforms are separated by a succession of shoshonitic basaltic dykes, volcanic breccias, and pillowed lava flows accumulated in basins (Bosellini et al. 1996, 2003). In the inter-platform basins silicic volcanic deposits accumulated ("pietra verde") during the late Anisian - late Ladinian inferred to be the precursor of the major volcanic phase (Bosellini et al. 2003).
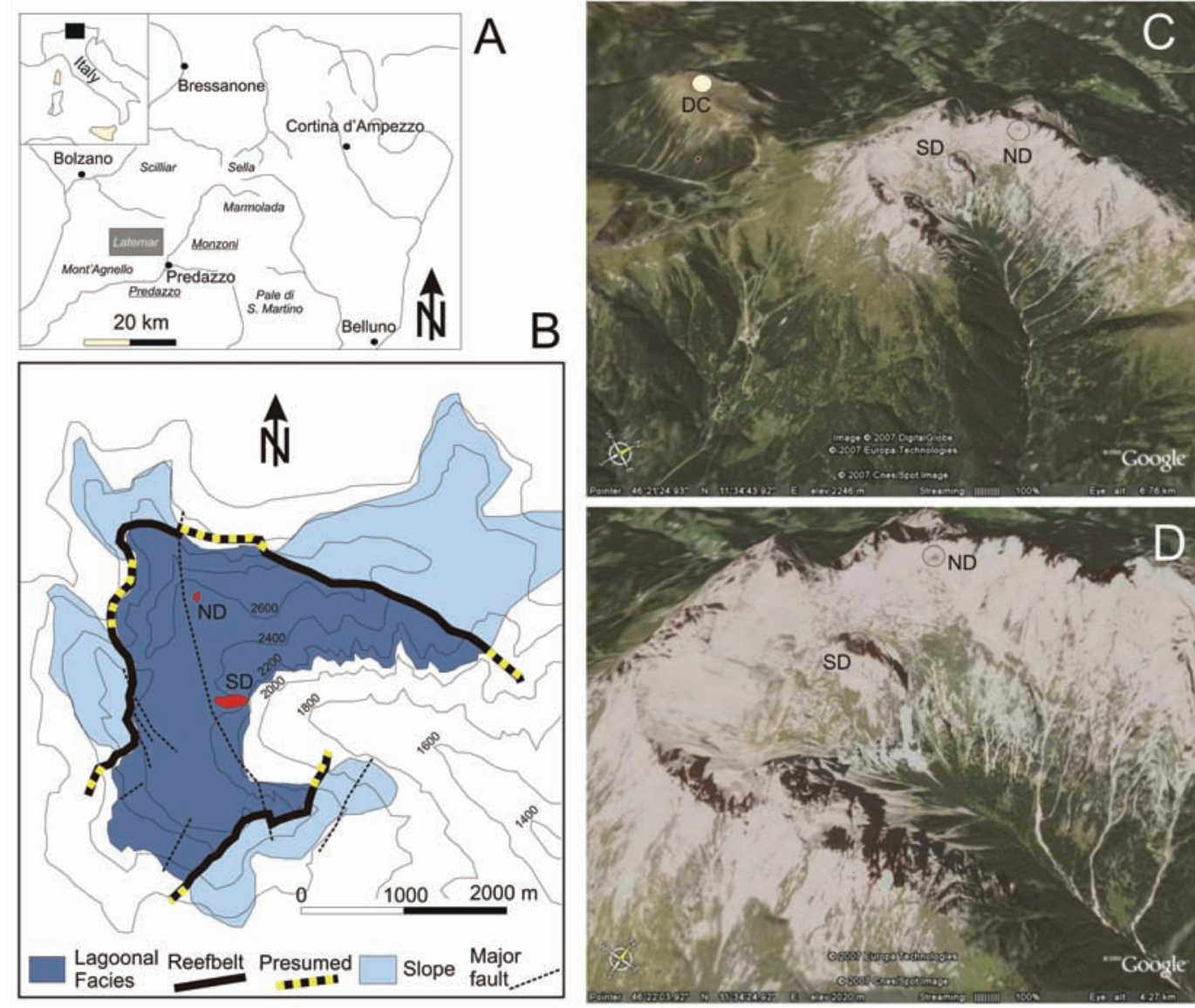

Figure 1. (A) The location of the Dolomites in northern Italy, and the study site of Latemar (rectangle). Carbonate platforms are named in italic, while Middle Triassic igneous intrusions are in italic and underlined style. Major towns are in bold. (B) Overview map of the Latemar. Carbonate platform facies distribution data is from Egenhoff et al.1999. ND-Northern Diatreme, SD-Southern Diatreme. (C) Oblique panoramic view (Google Earth) of the Latemar with the southern (SD) and northern (ND) diatremes marked in a circle. Dos Capello/Doss Capel section (DC) is located SW from the Latemar. (D) Close up oblique view (Google Earth) of the Latemar with the southern (SD) and northern (ND) diatremes in the centre of the carbonate platform.

\section{Diatremes identified}

\section{from the Latemar}

The Middle Triassic carbonate platform of the Latemar is cut through by two well distinguished volcaniclastic breccia-dominated zones (Figs. 1B, C, D). Each zone is about $200 \mathrm{~m}$ in diameter. The southern site, referred here as southern diatreme, is east to west elongated and forms a characteristic ridge in the middle of the present day surface (Fig. 1B). The northern site, referred here as northern diatreme is more circular in map view, and forms only a small, elevated body in the carbonate rock units. This site has at least two welldistinguished smaller zones just few metres across.

\section{Southern Diatreme}

This site has a characteristic morphological feature in the middle of the platform (Fig. 2A). The preserved hill consists of mafic volcaniclastic breccia elevated about $200 \mathrm{~m}$ above the surrounding carbonate units (Fig. 2B). The elongated feature exposes characteristic fault zones. 
Between these fault zones, tilted, and collapsed blocks of the platform are exposed, surrounded by volcaniclastic breccias. Outside of these pipe-like bodies, the platform exposes sub-horizontal bedding structure, which makes this pipe well-distinguished from the surrounding platform facies (Fig.2A). The volcaniclastic breccia consists of mafic basaltoid clasts up to few $\mathrm{dm}$ in diameter. The volcanic fragments are black, having chilled, thick margins, and other than quench crystals, have no significant phenocrystal contents. Chilled volcanic fragments of lapilli size and cauliflower shaped bombs, and large volume of accidental lithic rocks are the main particles in the volcanic breccia. The volcanic fragments are predominantly angular in shape with sharp edges (Fig. 2C). The volcanic breccia, dominated by clasts (Fig. 2D) has larger volume of matrix in the upper part of the section, but it is not more than 40 vol. $\%$ by visual estimates. The matrix of the volcanic breccia is fine to coarse grained ash, dominated by dark and brownish variously altered volcanic glass shards and dispersed fragments of angular shape carbonate rocks. The volcanic breccia has no apparent structure such as stratification or bedding, however, juvenile fragment enriched few metres wide, and irregular shaped vertical zones are apparent. The volcanic breccia contains a large amount of dm-sized carbonate rock fragments with rounded to angular shape (Figs. 2C, D). Larger carbonate rock fragments seem to form clusters. The proportion of carbonate fragments in the upper pipelike zone increases and about equals the volume of volcanic and nonvolcanic clasts. The boundary of the pipe-like volcanic breccia zone is irregular, and large fractured carbonate fragments form a few metres wide transition zone between the volcanic breccia and the host platform carbonate. At the base of the volcanic breccia horizon, irregular shape, cm-to-dm wide, chilled margined mafic dykes are common. The majority of the volcanic fragments contain large volume of xenocryst and peridotite lherzolite fragments with a diameter of few cm to dm (Fig. 3A, B). Large (dm-scale) lherzolite fragments seem to be covered by thin (mm-to-cm) glassy basaltic rim. The termination of these dykes is gradual to a juvenile fragment-rich zone in the volcanic breccia. Small dykes of irregular shape can be traced over few metres length into the host carbonate rocks in and along the margin of the volcanic breccia and host rock interface (Fig.3C, D). These dykes seem to follow fracture zones of the host carbonate rocks. No peperitic contact has been recognized. From fresh dyke fragments $\mathrm{K} /$ Ar age determination was performed and gave an age of the intrusive rocks to $204 \pm 7.8$ My (measurement by Kadosa Balogh, ATOMKI, Debrecen, Hungary). Along the volcanic breccia pipe, especially near its basal zone strong dolomitization of the surrounding host carbonate rock can be recognized.

In the top section of the volcanic breccia pipe, large (tens of metres across) tilted blocks of the platform can be distinguished. They are tilted over 20 degrees towards the centre of the volcanic breccia pipe (Figs. 2A, B). These blocks in the volcanic breccia pipe are surrounded by chaotic volcanic breccia.

\section{Interpretation}

The contact of the volcanic breccia and the host platform carbonate rocks gives evidence that the volcanic processes were able to accumulate fragmented volcanic rock in a subvertical fashion. The explanation for this facies architecture is to infer that the volcanic debris is part of a sub-vertical former volcanic conduit filled by a mixture of non-volcanic and volcanic rock fragments due to explosive volcanic eruption(s). Large, tilted megablocks of the host platform collapsed into the growing volcanic conduit, crater. Large blocks can collapse into the crater/conduit of a volcano, which are successfully able to excavate large volume of country rock during explosive eruptions (Lorenz et al. 1970; White, 1991b; Kurszlaukis and Barnett, 2003). Such mechanism is well known in maar forming eruptions, when the magma interacts with water and generates phreatomagmatic explosion, that are able to lift the country rock roof and form a large, unstable cavity into which intact megablocks can slide (Lorenz, 1971, 1975, 1986). Evidences of chilled volcanic fragments, cauliflower shaped bombs, large volume of accidental lithics in the volcanic 

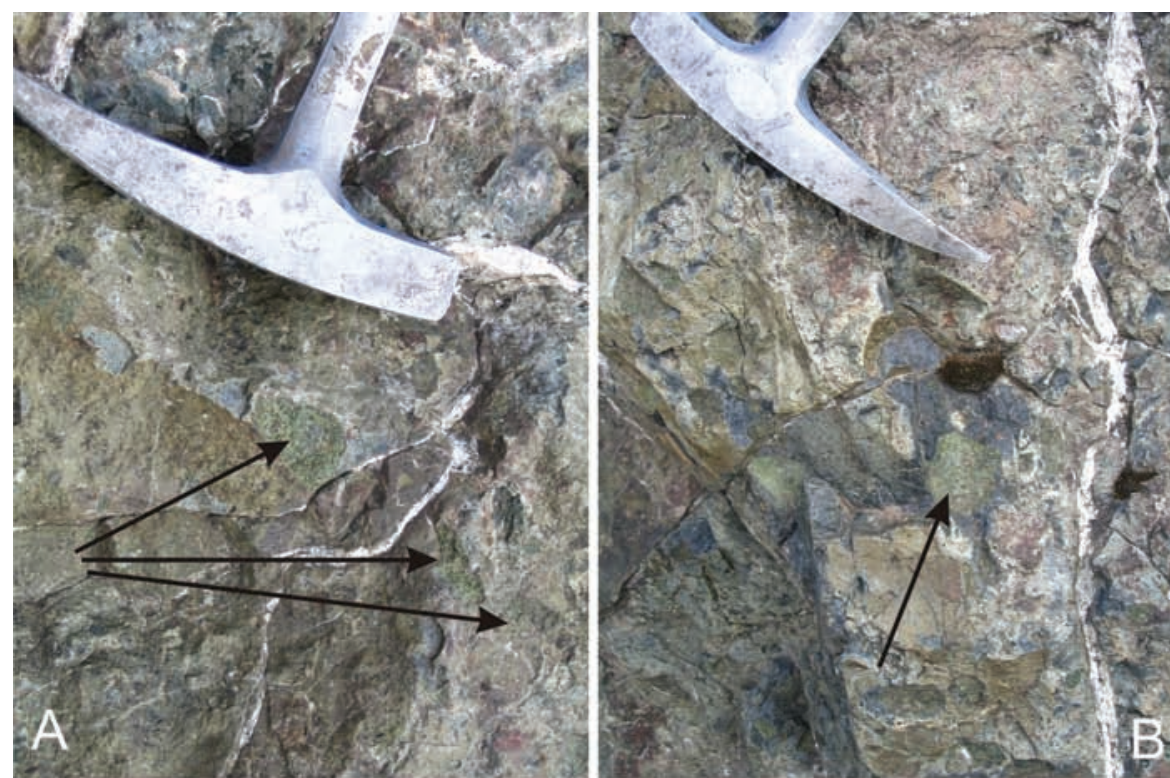

suggested, and preferred on the basis of large amount of angular shape and/or milled, semirounded carbonate country rock fragments in the volcanic breccia. The base of the volcanic breccia pipe is dominated by coherent volcanic rock facies, many of them forking and/or gradually extending into fragmented, juvenile volcanic rock fragment dominated zones (Lorenz and Kurszlaukis, 2007). This textural relationship indicates that the present day exposure is the zone where the intruding mafic dykes' initial fragmentation took place, e.g. contact zone of magma and water triggered the phreatomagmatic explosions (Lorenz and Kurszlaukis, 2007). The intruding dykes were choked with mantle-derived peridotite lherzolite fragments, suggestive of direct deep source and diatreme-like emplacement of the dykes.
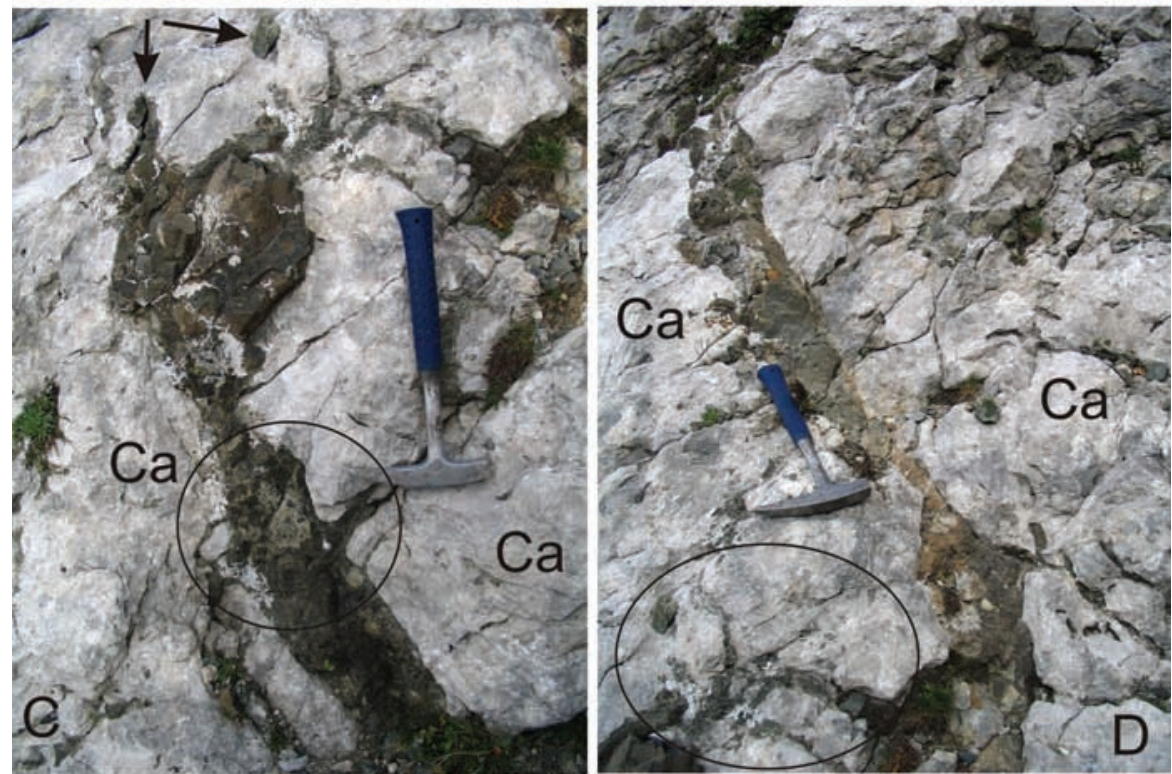

\section{Northern Diatreme}

Just about $1 \mathrm{~km}$ north from the previous volcaniclastic breccia pipe another volcanic breccia zone crops out (Fig. 1B). This volcanic breccia zone, however, does not form characteristic morphological feature, it is slightly elevated above its surrounding platform carbonate host rock units (Fig. 4A). The elevation of these exposures is more or less the same as the base of the previous volcaniclastic breccia pipe (Fig. 1B). The host rock bedding and other structural elements indicate that this volcaniclastic breccia horizon is in the same stratigraphic horizon and embedded (cut through) the platform edifice. The texture of this volcaniclastic breccia horizon is different from the southern volcaniclastic breccia pipes. It has no bedding in its central zone (Figs. 4B, $\mathrm{C})$, however, in its marginal zone slight stratification and grading gives a sub-horizontal fabric to the volcaniclastic breccia defined by larger fragment clusters (Fig. 4D). The clast to matrix ratio is less in comparison to pyroclastic rocks of the southern volcaniclastic breccia pipes (Figs. 4B, C). Here the volcaniclastic breccias' matrix can reach 60 vol. $\%$ by visual estimates. The matrix of the pyroclastic

breccia are all indicative of magma-water interaction driven explosive eruptions (Fisher and Schmincke, 1984). The predominantly angular texture of the carbonate country rock fragments in the volcanic breccia, as well as the presence of large, intact slide in megablocks indicate that the country rock (platform carbonate) was already consolidated, hard rock at the time the volcanism took place (Lorenz, 2003; Auer et al. 2007). However, irregular shape small dykes with bulbous margin in the contact zone of the volcanic breccia and the host carbonate rock unit is suggestive of zones of less consolidated and/or presence of wider textural zones in the carbonate units, that were invaded by dykes. The rigid nature of the host carbonate platform units is also breccias is brown in colour and coarse ash to fine lapilli in grain size. The matrix consists of palagonitized volcanic glass shards, co-genetic volcanic lithics, angular shape carbonate rocks and other exotic rock fragments derived from older (probably Permian) ignimbrite and associated volcaniclastic sequences (Figs. 4B, C). These fragments are evenly distributed in the entire volcaniclastic breccia with no preferred orientation and/or clustering texture. The lapilli or larger size clasts are dominated by angular shape carbonate fragments (about $75 \mathrm{vol} . \%$ of the larger than $1 \mathrm{~cm}$ grain size fraction by visual estimates). The carbonate fragments are usually strongly dolomitized but have no evidences of thermal influences. Larger 

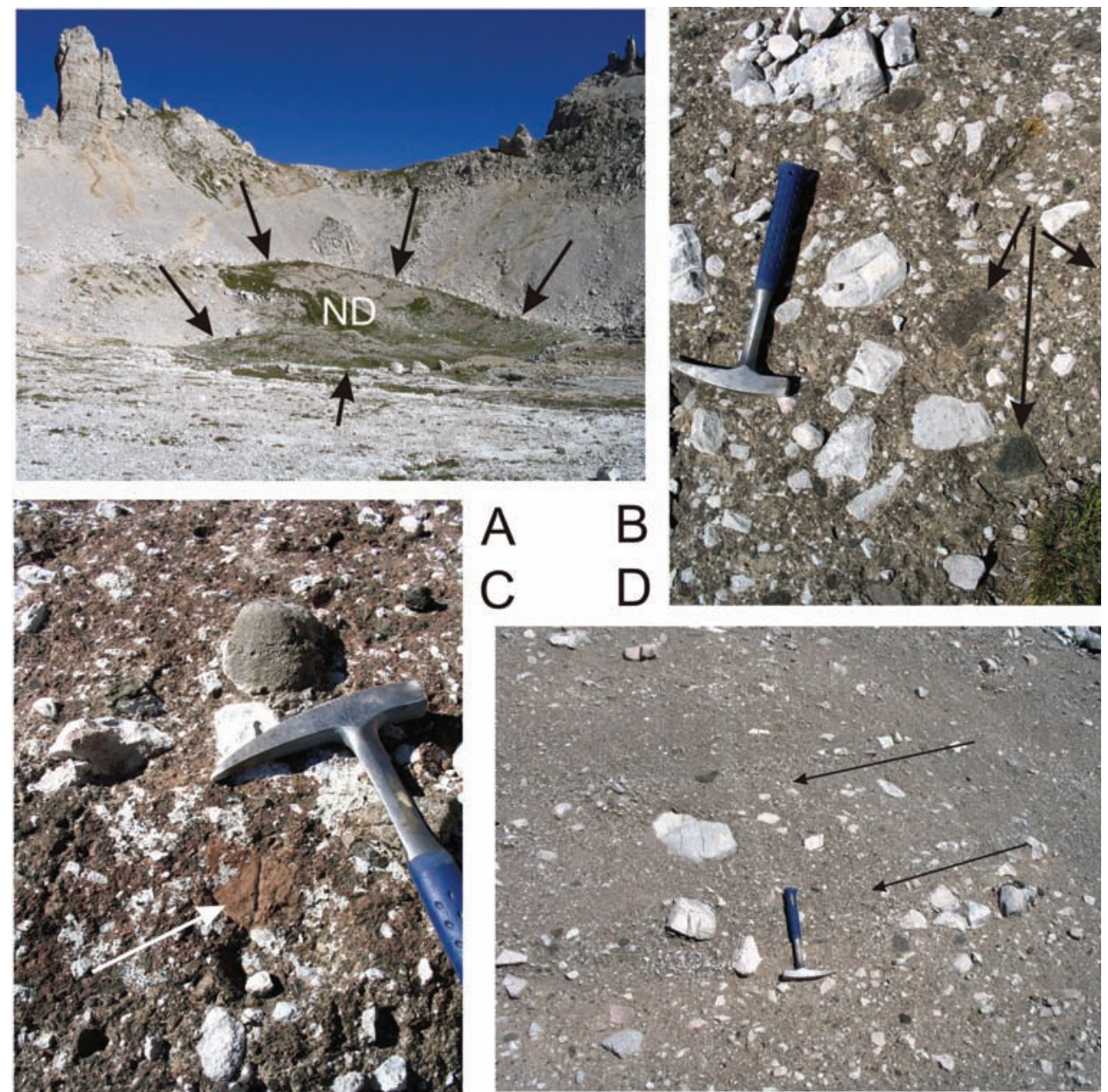

Figure 4. (A) Overview of the volcanic breccia of the northern diatreme (ND) with semi-circular map view (arrows). (B) Chilled, strongly palagonitized juvenile lapilli (arrows) in the volcanic breccia of the northern diatreme. (C) Angular shape Permian volcaniclastic rock fragment in the unsorted, matrix supported pyroclastic breccia of the northern diatreme (white arrow). (D) Weak stratification close to the margin of the pyroclastic breccia of the northern diatreme. Weak stratification is defined by clast alignments and fine enriched thin layers (arrows).

carbonate clasts form clusters, or breccia pipe margins in the lensoid zones. Largest carbonate clasts reach a metre in diameter however the average clast size is about $5 \mathrm{~cm}$. In this volcaniclastic breccia location, no peridotite lherzolite fragments have been identified, which is a significant difference from the southern outcrops. Also, in this location no coherent intrusive bodies are associated with the volcaniclastic breccia. The boundary of the volcaniclastic breccia is semicircular in map view and irregular, but no fractured host rock zones can be identified (Fig. 4A). The texture of the volcanic breccia here is different from the previous volcanic breccia. Three main differences can be pointed out; (1) the more matrix-rich character here, (2) lack of coherent magmatic bodies intruding the volcanic breccia and (3) lack of peridotite lherzolite fragments in the volcanic breccia.

\section{Interpretation}

The semicircular distribution of the volcanic breccias and their limited extent suggest that the identified volcanic breccia zone is part of a sub-vertical volcanic pipe (Lorenz et al. 1970; Lorenz, 1985). The lack of any other outcrop of similar volcanic breccias nearby indicates that the identified volcanic breccia is in sub-vertical contact with the host carbonate rocks, and part of a former volcanic conduit, rather than an erosional wedge-like remnant of a formerly more extensive volcanic breccia horizon. The presence of angular to milled shaped carbonate fragments, cauliflower bombs, glassy rimmed volcanic lapilli are indicative of magma and water interaction triggered phreatomagmatic explosive eruption as a cause for the generation of the volcanic breccia (Fisher and Schmincke, 1984). The non-bedded, massive nature of the volcanic breccia indicates deposition of high particle concentration, probably en mass fallback of fragmented debris into the volcanic conduit. The palagonitization of the volcanic lapilli and ash suggest water circulation and elevated temperature in the depositional site, also a supporting evidence for the volcanic conduit origin of the identified location (Lorenz, 1974). The large volume of accidental lithic fragments from the surrounding carbonate rock units, and subordinately from underlying Permian ignimbrite and/or ignimbrite related volcaniclastic rock facies suggests that the explosions took place in these rock units below the syn-volcanic surface. The present day exposure is inferred to represent a deep zone of the volcanic breccia-filled pipe conduit (White, 1991b; Lorenz and Kurszlaukis, 2007). The lack of coherent dykes in the present day exposure, however, suggests that this

zone is already the region where the intruding dykes completely fragmented, and probably represents the lower diatreme of a former phreatomagmatic volcano. In this respect, this northern volcanic breccia pipe represents a higher volcanic stratigraphic level than the southern breccia pipe, which is more consistent with an exposed root zone of a diatreme of a former phreatomagmatic volcano. The present day few tens of metres higher position of the northern diatreme exposures in comparison with the base of the southern diatreme is in agreement with this interpretation, however, the two volcanic structures might have been different in size. The weak stratification of the upper part (northern side) of the exposed volcanic breccia suggests some sort of pyroclastic density, current transportation and deposition inside the volcanic conduit (Lorenz and Kurszlaukis, 2007). Each phreatomagmatic explosion potentially triggered a radial moving base surge that deposited its clasts in the growing and continuously widening volcanic conduit. The lack of plastically deformed accidental lithic clasts in the volcanic breccia indicates that the volcanic conduit wall, the country rock was already consolidated at the time of volcanic explosions. The lack of peridotite lherzolite clasts in the volcanic breccia could be a sign that shallower magma sources triggered the volcanic eruption. 


\section{Other evidences of mafic phreatomagmatic volcanism}

About $3 \mathrm{~km}$ to the SW from the Latemar platform an isolated hillside exposes complex Triassic sedimentary successions at the Dos Capello/Doss Capel (Fig. 1A, C, D). The entire sedimentary succession with typical fine grained silicic volcaniclastic turbidity current deposits is topped by a subhorizontaly bedded volcanic succession with about $20 \mathrm{~m}$ total exposed thickness (Fig. 5A). This unit consists of alternating coarse and fine lapilli tuff and tuff beds with large volume of accidental lithic clasts of carbonate units (Fig. 5B, C). The coarse grained lapilli tuff beds predominantly consists of mafic angular shape, moderately vesicular volcanic fragments and angular carbonate rock fragments. The coarser lapilli tuff beds contain armoured lapilli and bombs of juvenile pyroclasts. Low angle cross bedding is characteristic in the finer grained tuff beds. The upper and lower bedding planes of these coarse grained lapilli tuffs are undulating but the bed thickness is persistent in a 25$35 \mathrm{~cm}$ range over tens of metres distances (Fig. 5B). Fine grained lapilli tuff and tuff beds are massive to cross-bedded, and contain occasionally larger clasts with impact sags (Fig. 5D). The matrix of the tuffs and lapilli tuffs are altered volcanic glass shards with angular shape carbonate fragments (Fig. 5D). No peridotite lherzolite fragments have been recognised yet from this site. The exposed volcaniclastic units are unsorted to moderately sorted. No obvious grading has been recognized.
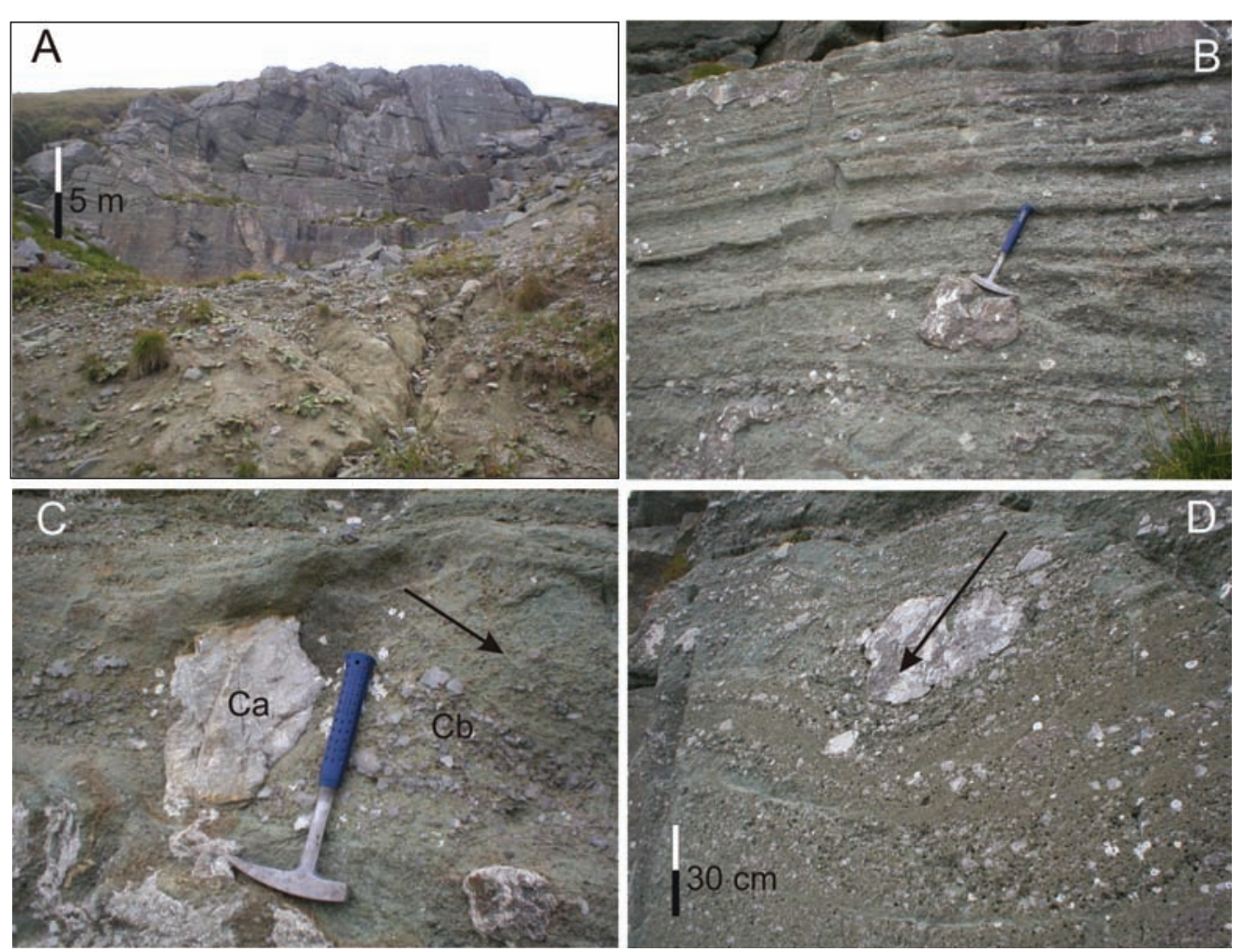

Figure 5. (A) Overview of an alternating lapilli tuff and tuff succession of the Dos Capello/Doss Capel phreatomagmatic volcanic succession. (B) Characteristic, rhythmic fine - coarse lapilli tuff and tuff beds of the Dos Capello/Doss Capel section. (C) Large carbonate block (Ca) in a lapilli tuff of the Dos Capello/Doss Capel section. Note the clast accumulation behind the large clasts $(\mathrm{Cb})$, and the fine enriched, slightly cross bedded zone (arrow) developed over the clast accumulation zone, all indicative of deposition from a horizontal moving pyroclastic density current. (D) Impact sag caused by a large accidental lithic clast (carbonate fragment) in the matrix rich lapilli tuff unit (arrow) of the Dos Capello/ Doss Capel section.

\section{Interpretation}

The exposed succession of Dos Capello/Doss Capel can be interpreted as part of a tuff ring formed during phreatomagmatic explosions. The entire succession is dominated by pyroclastic density current deposited units as indicated by the presence of cross bedding, of the exposed sections (Heiken, 1971; Lorenz, 1986; Mastrolorenzo, 1994, Sohn, 1996; Martin and Németh, 2005). The altered juvenile ragments with rims and homogeneous texture indicate original checks in an erupting vent site. This textural characteristic is armoured lapilli and bombs as well as fine grained pisolitic textrc inferred to be accretionary lapilli also suggests magma water interaction, and potential recycling of pyroclasts in a vent site before they were successfully carried away by pyroclastic density currents. The low angle cross bedding as well as the dune beds with angular and glassy pyroclastic rich beds indicate base surge dominated currents leaving the vent sites. The large amount of accidental lithic fragments in the pyroclastic succession suggests relatively closed conduit conditions and/or explosive eruption in the carbonate country rock units (White, 1991b). These conditions can meet in tuff

ring forming eruptions where magma interacts with groundwater. The hydrogeological nature of carbonate rocks is typical as fracture controlled aquifers (Aranda-Gomez and Luhr, 1996). In these rocks water can be stored in fractures, cavities, karst holes, caves; all might be encountered by rising magma (Aranda-Gomez and Luhr, 1996, Németh et al. 2001). Upon contact with water used in the magma water interaction in fracture controlled aquifers, water can be recharged quickly through the open fractures (Aranda-Gomez and Luhr, 1996). As a result, explosion locus could stay in the same position during the course of the eruption due to the continuous recharge of the water through the fracture network of the country rock. The exposed succession in Dos Capello/ Doss Capel hill is inferred to be part of a proximal succession of a tuff ring developed over carbonate rock units. The location of the vent is uncertain, however, it cannot be more than a few kilometres from the outcrops. The interpretation of the eruptive environment is likely to have been subaerial due to the large amount of fragmented 
country rocks in the pyroclastic succession as well as by the presence of well-developed impact sags caused by large fragments. Eruption on the seafloor would result in limited excavation of country rocks probably only due to volcanic conduit collapses. However, such processes would likely have excavated limited volume of country rocks. Phreatomagmatic explosive eruptions have been inferred from subaqueous guyot over carbonate platform from the western Pacific (Martin et al. 2004). However, the carbonate clasts in this location in the pyroclastic successions indicate their semiconsolidated state, and they form significant volume of the matrix of the pyroclastic rocks as limy mud (Martin et al. 2004). The pyroclastic rock facies of Dos Capello/Doss Capel contains predominantly angular clasts more consistent with their original consolidated, hard rock texture at the time these fragments were ejected by volcanic explosions. Shallow water eruption in the Dos Capello/Doss Capel region cannot be ruled out, but the textural characteristics of the pyroclastic rocks are more indicative for sub-aerial eruptions or eruption through enough shallow water column that the explosions can quickly pierce.

\section{Implication for carbonate platform evolution}

In late Anisian time, the Dolomites formed part of a continental shelf on the northwestern rim of the Tethys ocean (Dercourt et al. 1993; Bosellini et al. 2003). The Middle and early Upper Triassic stratigraphy of the Dolomites is dominated by the high relief carbonate buildups of the Schlern and Cassian Formation (Bosellini et al. 2003). Early Middle Triassic buildups developed on the laterally continuous carbonate bank of the Contrin Formation as a consequence of rapid tectonic subsidence (Gaetani et al. 1981; Bosellini, 1984; Maurer, 2000; Bosellini et al. 2003). These buildups are the time equivalents of the thin pelagic limestones and dominantly silicic volcaniclastic units of the Buchenstein beds (Bosellini et al. 2003). The Cassian platform often top the older Schlern platform after a period of mafic volcanism around the Predazzo and Monzoni igneous bodies (Pisa et al. 1980). The Middle Triassic platform of the Latemar is built up by the Schlern Formation that consists of predominantly limestone lithology formed before mafic volcanism took place in the region (Pisa et al. 1980). The new K/Ar age (using method described in Balogh and Németh, 2005) derived from coherent magmatic body of the identified southern diatreme in the centre of the Latemar gave an age of $204 \pm 7.8$ My which is consistent with the younger age of the volcanic conduit cut through the platform edifice, and suggests diatreme volcanism about 25 million years after the formation of the platform (Fig. 6). In many cases the Longobardian (late Ladinian) carbonate production is inferred to have ceased due to magmatotectonic events lasting until the Carnian (Pisa et al. 1980). The products of this predominantly mafic volcanism are various pyroclastic and coherent, pillow-lava dominated successions (Wengen Group). The Latemar is commonly considered as an atoll-like carbonate platform about $3 \mathrm{~km}$ across with an extensive internal lagoon facies (Egenhoff et al. 1999). The preserved diatremes cut through these lagoonal facies in the centre of the present day Latemar. Due to the significant time difference between the inferred age of the carbonate platform of the Latemar, and the coherent magmatic body of the southern diatreme, it is inferred that the volcano, cut through the carbonate buildup, postdates the active depositional phase of the platform itself.

Duration of the formation of the $800 \mathrm{~m}$ thick carbonate sequence of the Latemar platform was highly debated (Brack et al. 1996; Bechstadt et al. 2003). The maximum time length was calculated to be about 12 My on the basis of about 600 metre-scale cycles that were caused by high-frequency orbitally induced Milankovitch cyclicity (Goldhammer et al. 1987; Goldhammer et al. 1991; Hinnov

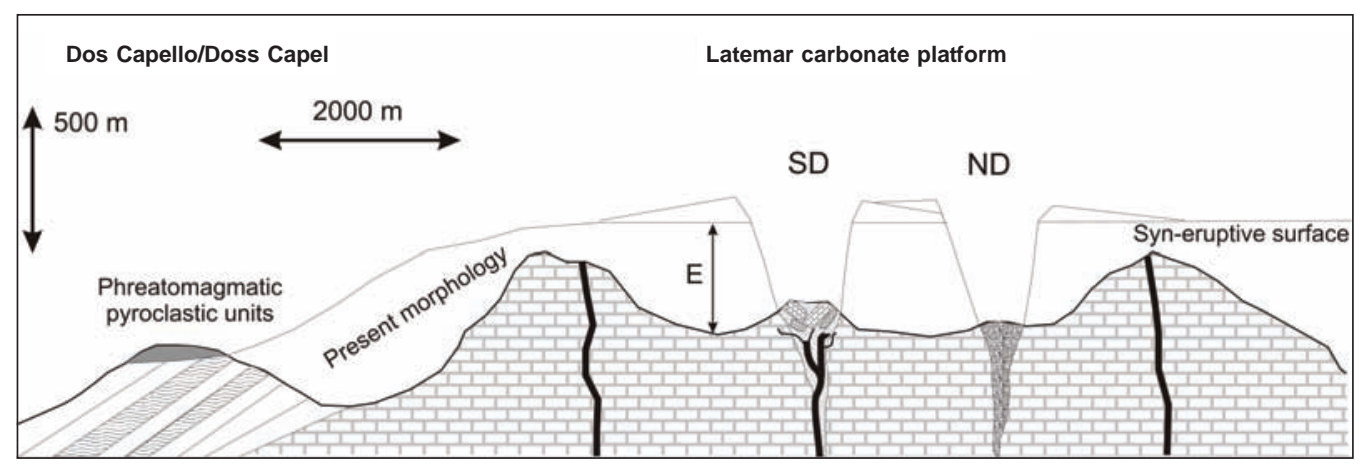

Figure 6. Theoretical cross section from the Dos Capello/Doss Capel to the Latemar carbonate platform. The southern (SD) and northern (ND) diatreme represent a root zone/lower diatreme of a phreatomagmatic volcano while the Dos Capello/Doss Capel succession is part of a volcanic flank facies of a phreatomagmatic volcano (e.g. tuff ring). The geometrical parameters of the preserved diatremes suggest that this exposed volcanic pipes represent few hundreds metres below the syn-volcanic paleosurface levels. The erosion (E) therefore estimated to be in few hundreds of metres scale. A general agreement about the accumulation rate of the Latemar carbonate platform states that it was developed over few millions of years of platform growth. Applying same growth rate to the missing (eroded) units above the top of present day exposures of the Latemar group (about 200 metres) it is inferred that the former phreatomagmatic volcanoes (maars) erupted on a subaerially exposed (dead) carbonate rock landscape simply because the measured $\mathrm{K} / \mathrm{Ar}$ age of the southern diatreme is too young in comparison to the estimated age of the syn-eruptive paleosurface. Therefore the maar/diatreme volcanoes are unlikely causes of the end of the carbonate platform growth of the Latemar unless extremely slow growth rate is inferred, that would fill the "time gap" between the onset of eruption and the timeframe represented by the preserved top level of the present day Latemar platform carbonates. and Gold-hammer, 1991). Combination of biostratigraphy and radiometric dating, however, challenges this cyclostratigraphic interpretation (Brack and Rieber, 1993; Brack et al. 1996; Mundil et al. 1996; Brack and Muttoni, 2000). On the basis of age-diagnostic fossils (mainly ammonites) and $\mathrm{U}-\mathrm{Pb}$ ages of zircons of volcaniclastic interlayers, the duration of the accumulation of the Latemar succession is inferred to be only between 2 and 4.7 My. If the identified diatreme volcanism was the reason to stop the growth of the platform, and we accept the long (12 My) accumulation history of the Latemar ( 800 metres thick carbonate buildup), at least about 1000 metres platform buildup had to accumulate before the maar/ diatreme volcanoes erupted 
through this huge carbonate platform (Fig.6). From the lower diatreme - root zone volcanic facies architecture and its geometrical parameters identified in the centre of the Latemar, the present exposure level of the diatremes could be about 1000 metres below the synvolcanic paleosurface, especially inferring ongoing subsidence and reorganisation processes in the volcanic conduit after the volcanic activity (Lorenz, 1986; Suhr et al. 2006). The accuracy of the K/Ar age determination hindered by advanced alteration of the coherent basaltic rocks which allows only a very rough establishment of the time relationship between the diatremes and the preserved platform carbonates. Therefore, further detailed studies are needed to develop this idea. If we accept a relatively fast accumulation rate of the carbonate platform, the time gap between the diatreme forming eruptions and the formation of the preserved platform is simply too large to link the volcanism as a cause of the death of the active carbonate platform (Fig.6). At this stage more independent evidences point to infer that the identified diatreme volcanism post-date the carbonate platform development in the Latemar. The maar/diatreme volcanoes erupted through an already diagenetized, and probably subaerially exposed, gradually eroding carbonate platform, forming a near sea-level low lands (Fig. 6), similar to the present day landscape of Yucatan in Mexico.

Significant time difference between the age of the platform and the diatreme volcanism suggests that the volcano developed in an environment with high water accessibility, but very likely under subaerial conditions. The large number of accidental lithic clasts in the conduit filling volcanic breccias indicates an explosive eruption inside carbonate platform. Due to fracture-controlled hydrological conditions, carbonate rock magma-water interaction was likely to have taken place in water filled pre-existing fracture zones. The angularity of the carbonate rock fragments in the volcanic breccias, as well as the lack of plastically deformed former lime mud chunks attests the idea that the country rocks were rigid and stable during the volcanic eruptions. In such conditions, relatively deep and wide volcanic conduit can develop, filled with volcanic debris mixed with disrupted wall rock material, similar to those deep maars developed over karstic limestone bedrocks in Durango, Mexico (Aranda-Gomez and Luhr, 1996). The eruption through a carbonate dominated country rock succession with karst water system filled fractures can excavate large volcanic depressions that may be connected to deep diatremes, similar to young maar volcanoes on carbonate lands, such as Joya Honda in Mexico (Aranda-Gomez and Luhr, 1996). The textural differences between the volcanic breccias of the northern and southern diatremes suggests that they represent two different volcanic stratigraphic levels of two phreatomagmatic volcanoes with different sizes. The large collapsed carbonate blocks exposed in the southern diatreme suggest whole-scale maar-like volcanic depression where the country rock blocks subsided after the excavation of the volcanic crater. Similar collapsed blocks in phreatomagmatic volcanoes erupted through a hard country rock environment are well documented in many places (Lorenz, 1971, 2003; Auer et al. 2007). The predominantly hard country rock environment in the Latemar phreatomagmatic volcanoes suggests that these volcanoes might have been rather large with wide (more than a kilometre) and deep (more than hundred metres) maar craters. In this way, the location, and spacing of these two diatreme suggests two closely spaced maar volcanoes could have occupied the entire lagoonal facies zone of the carbonate platform at the Latemar. The interpretation of these identified diatremes as a root and lower diatreme zones suggests that they represent a rather deep, exposed part of a maar-diatreme volcano. The diameter and facies architecture of the preserved diatremes suggest that they represent at least few hundred metres below the syn-volcanic paleo-surface levels (Lorenz, 1986). This would imply that the present day top of the southern diatreme would also represent at least few hundred metres below the syn-volcanic paleo-surface level.

Pyroclastic successions in the nearby Dos Capello/Doss Capel hill also indicate phreatomagmatic volcanism slightly post-dates the main phase of the evolution of the Latemar platform. The identified mafic pyroclastic density current deposit-dominated successions overlay pelagic limestones and dominantly silicic volcaniclastic units of the Buchenstein beds. The contact between these rock units is not exposed, but judging from the general bedding characteristics an unconformity is expected between these two rock units. The textural characteristics of these pyroclastic succession is indicative for subaerially accumulated base surge and pyroclastic fall dominated primary successions, formed due to phreatomagmatic volcanism. Dos Capello/Doss Capel successions are inferred to be a lateral, distal facies equivalent of the volcanic facies of the diatremes in the centre of the Latemar about $3 \mathrm{~km}$ away. However, the correlation between these proximal (diatreme) and distal (volcanic flank) facies in the Latemar - Dos Capello/Doss Capel region is almost impossible. The significance of the identification of phreatomagmatic volcanism generated pyroclastic successions of volcanic flank facies is that the location of these preserved units at Dos Capello/Doss Capel clearly marks a syn-volcanic paleo-surface where the tephra of the phreatomagmatic explosive eruptions accumulated (Fig. 6). Also, the bedding, texture, clast morphology and flow indicators identified from the Dos Capello/Doss Capel succession are more consistent with subaerial accumulation, and suggest tuff ring formation in an already subaerially exposed landscape.

The identified volcanic breccias in the centre of the Latemar as exposed diatremes also highlight the need to re-examine many volcanic breccias reported from Triassic carbonate platforms of the Tethys. These volcanic breccia zones could be exposed volcanic pipes, diatremes, remnants of former phreatomagmatic volcanic fields developed over an already subaerially exposed and eroding carbonate rock dominated low-laying landscape. The main phase of the latest Anisian explosive volcanism in the Tethys realm such as in northern Italy or in the Transdanubian Range in western Hungary is characterized mainly by redeposited submarine volcanic deposits forming interbeds of volcaniclastic turbidites among pelagic carbonatic rocks (Pisa et al. 1980; Gaetani et al. 1981; Bosellini et al. 2003; Budai and Vörös, 2006). There are no evidences so far that this volcanic activity influenced the evolution of the Middle Triassic platforms. However, Neptunian dykes penetrating the Ladinian platform prove extensional tectonic activity during the Longobardian that might have controlled the subsidence of the platform margins (Budai and Vörös, 2006). Identification of diatremes in the centre of the Latemar indicates that mafic explosive volcanism took place either in the final stage of the platform development or slightly after its death and subaerial exposure. However, the diatreme volcanism is considered to be a result of small volume, generally mafic phreatomagmatic volcanism which provides only limited volume of volcaniclastic sediment, unlike the explosive silicic eruptions, that might be able to effect hundreds of $\mathrm{km}^{2}$ of areas and feed turbidity currents that carry away volcanic detritus into the distal part of the surrounding basins. Detailed correlations between carbonate platforms and associated interplatform successions in the Dolomites region and 
in western Hungary also suggest that the main differences between the evolution of Middle Triassic platforms could have been effected very differently by volcanotectonic activity that was intensive in the western Dolomites but had much less influence in the Transdanubian Range, in Hungary (Budai and Vörös, 2006).

\section{Conclusion}

Identified volcaniclastic rock units in the central part of the Latemar carbonate platform are inferred to be exposed diatremes of eroded phreatomagmatic volcanoes (e.g. maars) (Fig. 6). The significant time gap between the measured age of coherent magmatic bodies recovered from one of the diatreme and the inferred age and time duration of the formation of the Latemar edifice is more consistent with maar-diatreme volcanism, which became active after the subaerial exposure and initial erosion of the platform. However, if the carbonate platform development at Latemar is accepted to have lasted tens of millions of years, phreatomagmatic volcanism through an active carbonate platform could have been the cause of the platform drowning. In spite of this theoretical possibility, the time duration seems to be too long to sustain such stable conditions for carbonate platform development, and we conclude that the identified diatremes erupted through an already inactive and eroding carbonate platform succession. The new identification of diatremes from the Latemar platform highlights the need for further investigations on volcanic breccias associated with other Triassic carbonate platforms of the Tethys. Many volcanic breccias interpreted to be results of tectonic activity which provided volcaniclasts to the active carbonate platforms. Here we have demonstrated that phreatomagmatic volcanism produced maar-diatreme volcanoes over carbonate platform successions. After erosion, the conduit filling volcanic breccias at the sub-surface part of these volcanoes were exposed. Therefore the identification of such volcanic breccias cannot testify for the role of volcanism as a cause of cease and tectonic collapse of the carbonate platforms. To infer the role of the identified volcanic features in the Latemar in the cease of carbonate platform growth would imply long time extent for the carbonate platform development (tens of millions of years), thick buildup of total carbonate platform accumulation before the volcanism (at least $2000 \mathrm{~m}$ ) and significant erosion $(\sim 1000 \mathrm{~m})$. These parameters and requirements are not unrealistic, but rather maximum values. Therefore, we cannot rule out the potential role of the identified and reconstructed two maar/ diatreme volcanoes in the central part of the Latemar as a direct cause for the cease of active carbonate platform growth, but inferring that these volcanoes erupted on already subaerially exposed carbonate landscape is more realistic.

\section{Acknowledgements}

Project supported by the Hungarian Research Found (OTKA T043341 BT), NZ-FRST Post-doctoral Fellowship (MAUX 405) (KN) and Massey University Research Fund (KN). Constructive reviews by Corina Risso (Buenos Aires) and Peter Suhr (Dresden) significantly elevated the quality of this report, many thanks for them.

\section{References}

Aranda-Gomez, J. J. and Luhr, J. F., 1996, Origin of the Joya Honda maar, San Luis Potosi, Mexico, Journal of Volcanology and Geothermal Research, 74, 1-18.
Auer, A., Martin, U. and Németh, K., 2007, The Fekete-hegy (Balaton Highland Hungary) "soft-substrate" and "hard-substrate" maar volcanoes in an aligned volcanic complex - Implications for vent geometry, subsurface stratigraphy and the palaeoenvironmental setting, Journal of Volcanology and Geothermal Research, 159, 225-245.

Balogh, K. and Németh, K., 2005, Evidence for the Neogene small-volume intracontinental. volcanism in western Hungary: K/Ar geochronology of the Tihany Maar volcanic complex. Geologica Carpathica, 56, 91-99.

Basile, C., and Chauvet, F., 2009, Hydromagmatic eruption during the buildup of a Triassic carbonate platform (Oman Exotics): Eruptive style and associated deformations. Journal of Volcanology and Geothermal Research, 183, 84-96.

Bechstädt, T., Brack, P., N., P., Rieber, H. and Zühlke, R., 2003, Field trip to Latemar. Guidebook. Triassic geochronology and cyclostratigraphy Field Symposium St. Christina/Val Gardena, Dolomites, Italy, Septemer 1113,2003

Bosellini, A., 1984, Progradation geometries of carbonate platforms: example from the Triassic of the Dolomites, northern Italy., Sedimentology, 31, $1-24$.

Bosellini, A., Neri, C. and Stefani, M., 1996, Geologia delle Dolomiti. Introduzione Geologica. Guida alla Escursione Generale., Societa Geologica Italiana, 120p.

Bosellini, A., Gianolla, P. and Stefani, M., 2003, Geology of the Dolomites., Episodes, 26, 181-185.

Brack, P. and Rieber, H., 1993, Towards a better definition of the Anisian/ Ladinian boundary: New biostratigraphic data and correlations of boundary sections from the Southern Alps., Eclogae geologicae Helvetiae, $86,415-527$.

Brack, P., Mundil, R., Oberli, F., Meier, M. and Rieber, H., 1996, Biostratigraphic and radiometric age data question the Milankovitch characteristics of the Latemar cycles (Southern Alps, Italy). Geology, 24, 371-375.

Brack, P. and Muttoni, G., 2000, High-resolution magnetostratigraphic and lithostratigraphic correlations in Middle Triassic pelagic carbonates from the Dolomites (northern Italy), Palaeogeography Palaeoclimatology Palaeoecology, 161, 361-380.

Brand, B.D., and Clarke, A.B., 2009, The architecture, eruptive history, and evolution of the Table Rock Complex, Oregon: From a Surtseyan to an energetic maar eruption. Journal of Volcanology and Geothermal Research, 180, 203-224.

Budai, T. and Vörös, A., 1993, The Middle Triassic events of the Transdanubian Central Range in the frame of the Alpine evolution. Acta Geologica Hungarica, 36(1), 3-13.

Budai, T. and Vörös, A., 2006, Middle Triassic platform and basin evolution of the Southern Bakony Mountains (Transdanubian Range, Hungary). Rivista Italiana Paleontologia Stratigrafia, 112, 359-371.

Caroff, M., Vidal, M., Bénard, A. and Darboux, J-R., 2009, A late-Ordovician phreatomagmatic complex in marine soft-substrate environment: The Crozon volcanic system, Armorican Massif (France). Journal of Volcanology and Geothermal Research doi: 10.1016/j.volgeores. 2009.05.002.

De Zanche, V., Gianolla, P., Mietto, P., Siorpaes, C. and Vail, P., 1993, Triassic sequence stratigraphy in the Dolomites (Italy). Memorie Scienze Geologiche, 45, 1-27.

Dercourt, J., Ricou, L. E. and Vrielynck, B., 1993, Atlas Tethys Palaeoenvironmental Maps. Late Murgabian $(266 \pm 264$ Ma); Late Anisian (237 $\pm 234 \mathrm{Ma}), 9-33$, maps. Gauthier-Villars, Paris.

Egenhoff, S. O., Peterhansel, A., Bechstadt, T., Zuhlke, R. and Grotsch, J., 1999, Facies architecture of an isolated carbonate platform: tracing the cycles of the Latemar (Middle Triassic, northern Italy), Sedimentology, 46, 893-912.

Fernández-Mendiola, P.A., and García-Mondéjar, J., 2003, Carbonate platform growth influenced by contemporaneous basaltic intrusion (Albian of Larrano, Spain). Sedimentology, 50, 961-978.

Fisher, R. V. and Schmincke, H.-U., 1984, Pyroclastic Rocks, Springer, Heidelberg, 474p.

Gaetani, M., Fois, E., Jadoul, F. and Nicora, A., 1981, Nature and evolution of Middle Triassic carbonate buildups in the Dolomites (Italy). Marine Geology, 44, 25-57.

Gianolla, P., De Zanche, V. and Mietto, P., 1998, Triassic sequence stratigraphy in the Southern Alps (northern Italy): definition of sequences and basin evolution. - In: Mesozoic-Cenozoic Sequence Stratigraphy of European Basins., SEPM Special Publication, 60, 723-751. 
Goldhammer, R. K., Dunn, P. A. and Hardie, L. A., 1987, High-frequency glacio-eustatic sea level oscillations with Milankovitch characteristics recorded in Middle Triassic platform carbonates in northern Italy., American Journal of Science, 287, 853-892.

Goldhammer, R. K., Dunn, P. A., Harris, M. T. and Hardie, L. A., 1991, Sequence Stratigraphy and Systems Tract Development of the Latemar Platform, Middle Triassic of the Dolomites - Outcrop Calibration Keyed by Cycle Stacking Patterns, AAPG Bulletin-American Association of Petroleum Geologists, 75, 582-582.

Heiken, G. H., 1971, Tuff rings: examples from the Fort Rock-Christmas Lake Valley Basin, South-Central Oregon, Journal of Geophysical Research, 76, 5615-5626.

Hinnov, L. A. and Goldhammer, R. K., 1991, Spectral analysis of the Middle Triassic Latemar Limestone, Journal of Sedimentary Petrology, 61, 11731193.

Kurszlaukis, S. and Barnett, W. P., 2003, Volcanological and structural aspects of the Venetia kimberlite cluster - a case study of South African kimberlite maar-diatreme volcanoes, South African Journal of Geology, 106, 165192.

Lorenz, V., McBirney, A. R. and Williams, H., 1970, An investigation of volcanic depressions. Part III. Maars, tuff-rings, tuff-cones and diatremes, Clearinghouse for Federal Scientific and Technical Information, Springfield, Va., Houston, Texas, 196p.

Lorenz, V., 1971, Collapse structures in the Permian of the Saar-Nahe area, Southwest Germany, Geologische Rundschau, 60, 924-948.

Lorenz, V., 1974, Studies of the Surtsey tephra deposits, Surtsey Research Program Report, 7, 72-79.

Lorenz, V., 1975, Formation of phreatomagmatic maar-diatreme volcanoes and its relevance to kimberlite diatremes, Phys. Chem. Earth, 9, 17-27.

Lorenz, V., 1985, Maars and diatremes of phreatomagmatic origin: a review, Transactions of the Geological Society of South Africa, 88, 459-470.

Lorenz, V., 1986, On the growth of maars and diatremes and its relevance to the formation of tuff rings, Bulletin of Volcanology, 48, 265-274.

Lorenz, V., 2003, Maar-diatreme volcanoes, their formation, and their setting in hard-rock or soft-rock environments. Geolines, 15, 72-83.

Lorenz, V. and Kurszlaukis, S., 2007, Root zone processes in the phreatomagmatic pipe emplacement model and consequences for the evolution of maar-diatreme volcanoes, Journal of Volcanology and Geothermal Research, 159, 4-32.

Manville, V., Németh, K., Kano, K., 2009, Source to sink: A review of three decades of progress in the understanding of volcaniclastic processes, deposits, and hazards. Sedimentary Geology doi: 10.1016/j.sedgeo. 2009.04.022

Martin, U., Breitkreuz, C., Egenhoff, S., Enos, P. and Jansa, L., 2004, Shallowmarine phreatomagmatic eruptions through a semi-solidified carbonate platform (ODP leg 144, site 878, early cretaceous, MIT Guyot, west Pacific), Marine Geology, 204, 251-272.

Martin, U. and Németh, K., 2005, Eruptive and depositional history of a Pliocene tuff ring that developed in a fluvio-lacustrine basin: Kissomlyó volcano (western Hungary), Journal of Volcanology and Geothermal Research, 147, 342-356.

Martin, U., and Németh, K., 2007, Blocky versus fluidal peperite textures developed in volcanic conduits, vents and crater lakes of phreatomagmatic volcanoes in Mio/Pliocene volcanic fields of Western Hungary. Journal of Volcanology and Geothermal Research, 159, 164-178.

Mastrolorenzo, G., 1994, Averno Tuff Ring in Campi-Flegrei (South Italy), Bulletin of Volcanology, 56, 561-572.

Maurer, F., 2000, Growth mode of Middle Triassic carbonate platforms in the Western Dolomites (Southern Alps, Italy), Sedimentary Geology, 134, 275-286.

Mundil, R., Brack, P., Meier, M., Rieber, H. and Oberli, F., 1996, High resolution U-Pb dating of Middle Triassic volcaniclastics: Time scale calibration and verification of tuning parameters for carbonate sedimentation., Earth and Planetary Science Letters, 141, 137-151.

Németh, K., Martin, U. and Harangi, S., 2001, Miocene phreatomagmatic volcanism at Tihany (Pannonian Basin, Hungary), Journal of Volcanology and Geothermal Research, 111, 111-135.

Németh, K, Cronin, S.J., Charley, D., Harrison, M. and Garae, E., 2006, Exploding lakes in Vanuatu - "Surtseyan-style" eruptions witnessed on Ambae Island. Episodes, 29(2), 87-92.

Németh, K., and Martin, U., 2007, Shallow sill and dyke complex in western Hungary as a possible feeding system of phreatomagmatic volcanoes in "soft-rock" environment. Journal of Volcanology and Geothermal Research, 159, 138-152.

Pisa, G., Castellarin, A., Lucchini, F., Rossi, P. L., Simboli, G., Bosellini, A. and Sommavilla, E., 1980, Middle Triassic magmatism in the Southern Alps. I.: A review of general data in the Dolomites., Rivista Italiana Paleontologia Stratigrafia, 85, 1093-1110.

Ross, P.S., White, J.D.L., Zimanowski, B., and Buttner, R., 2008a, Multiphase flow above explosion sites in debris-filled volcanic vents: Insights from analogue experiments. Journal of Volcanology and Geothermal Research, $178,104-112$

Ross, P.S., White, J.D.L., Zimanowski, B., and Buttner, R., 2008b, Rapid injection of particles and gas into non-fluidized granular material, and some volcanological implications. Bulletin of Volcanology, 70, 11511168

Ross, P.S., and White, J.D.L., 2006, Debris jets in continental phreatomagmatic volcanoes: A field study of their subterranean deposits in the Coombs Hills vent complex, Antarctica. Journal of Volcanology and Geothermal Research, 149, 62-84.

Sohn, Y. K., 1996, Hydrovolcanic processes forming basaltic tuff rings and cones on Cheju Island, Korea, Geological Society of America Bulletin $108,1199-1211$

Suhr, P., Goth, K., Lorenz, V. and Suhr, S., 2006, Long lasting subsidence and deformation in and above maar-diatreme volcanoes - a never ending story, Zeitschrift der Deutschen Gesellschaft für Geowissenschaften, 157, 491-511.

White, J. D. L., 1991a, The depositional record of small, monogenetic volcanoes within terrestrial basins. in Fisher, R. V. and Smith, G. A., eds, Sedimentation in Volcanic Settings: Tulsa (Oklahoma), Society for Sedimentary Geology, SEMP Special Publications, 45, 155-171.

White, J. D. L., 1991b, Maar-diatreme phreatomagmatism at Hopi Buttes, Navajo Nation (Arizona), USA, Bulletin of Volcanology, 53, 239-258.

White, J.D.L., 1996, Pre-emergent construction of a lacustrine basaltic volcano, Pahvant Butte, Utah (USA). Bulletin of Volcanology, 58, 249262 .

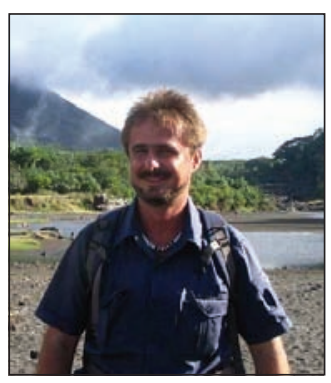

Karoly Nemeth is a Research Officer of the Volcanic Risk Solutions research group based in the Institute of Natural Resources of the Massey University. Nemeth's key duty is research on the field of volcanology, especially of mafic explosive volcanism and phreatomagmatism. He has been working on MioPliocene phreatomagmatic volcanoes in Central Europe (Hungary, Slovakia), and was the chairperson of the $2^{\text {nd }}$ International Maar Conference in 2004 held in Hungary.

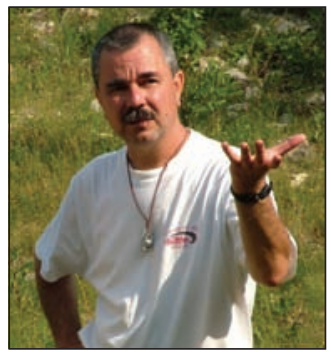

Tamás Budai (Doctor of the Hungarian Academy of Sciences) is a mapping geologist working for the Geological Institute of Hungary (MAFI). He is an expert in Triassic stratigraphy and carbonate sedimentology with special relevance to the evolution of the TransDanubian Range in West Hungary. He has compiled several map-sheets of the geological map series of Hungary and edited several monographs. He is the Chairman of the Sub-commission of Triassic Stratigraphy. 